\title{
Research Paper Export of spices from India: An instability analysis
}

\author{
n.U. Bagal, P.J. Kshirsagar, S.R. Torane and S.S. Manerikar
}

See end of the paper for authors' affiliations

Correspondence to :

P.J. Kshirsagar

Department of Agricultural Economics, Dr. B.S. Konkan Krishi Vidyapeeth, Dapoli (M.S.) India

Email: sagartarang@ rediffmail.com

Paper History :

Received : 27.01.2020;

Revised : 10.02.2020;

Accepted : 17.02 .2020
ABSTRACT : India has been known as land of spices and is also the largest consumer, producer and exporter of spices. India is the world's largest spices producer, with a 60 per cent share in output and 36 per cent in the global spices trade. The study was based on secondary data and analysis were conducted for 17 years from 2000-01 to 2016-17. The study showed a significant growth in export of spices from India during a study period. The annual compound growth rate of Indian spices export during 2000-01 to 2016-17 was accounted to 23.84 per cent per annum at 5 per cent significant level. The instability index for export quantity from India for all continents together was 51.82 per cent. There was instability in export during the study period for all continents of the world. It was also observed that, the instability indices for export value at current price and constant price were instable at overall level to all continents together.

KEY WORDS : Largest consumer, Producer, Exporter of spices

HOW TO CITE THIS PAPER : Bagal, N.U., Kshirsagar, P.J., Torane, S.R. and Manerikar, S.S. (2020). Export of spices from India: An instability analysis. Internat. Res. J. Agric. Eco. \& Stat., 11 (1) : 55-63, DOI : 10.15740/ HAS/IRJAES/11.1/55-63. Copyright@2020:HindAgri-Horticultural Society. 